\title{
The efficacy of medical dissolution therapy for uric acid nephrolithiasis
}

\author{
Senol Tonyali ${ }^{1}$
}

Received: 28 November 2019 / Accepted: 1 December 2019 / Published online: 6 December 2019

c) Springer-Verlag GmbH Germany, part of Springer Nature 2019

\section{Dear Editor,}

I read the article by Gridley et al. [1], which they evaluate the efficacy of medical dissolution therapy in patients having uric acid nephrolithiasis with great interest. They treated the patients either with only potassium citrate or with the combination of potassium citrate and allopurinol. However, I would like to highlight some issues regarding to the results of this study.

First of all, this is a retrospective study including small number of patients and based on identification of patients using ICD-9 codes. I think that one of the main limitations of this study is the lack of information about the stone composition. Presuming the stone composition regarding to the radiologic imaging or urine $\mathrm{pH}$ is not a reliable method for a scientific study. As the authors reported for a unique patient in the result section, those stones might have a mixed composition. The scheme of follow-up visits and the type of imaging modalities used in assessing stone status on followup are not standardized which might lead to inaccurate data. Using renal ultrasonography in defining stone clearance or reduction in total stone burden is not a reliable method, especially in renal stones smaller than $1 \mathrm{~cm} \mathrm{[2].} \mathrm{And} \mathrm{also}$ the reported mean BMI of the patients is $43.7 \pm 12.9 \mathrm{~kg} / \mathrm{m}^{2}$. I think ultrasonography might have drawbacks in such an obese patient cohort [3].

Uric acid nephrolithiasis is a systemic disorder necessitates complete metabolic evaluation prior to medical management [4]. In this study, only $12(50 \%)$ of the patients had a documented serum uric acid level prior to initiation of medical dissolution therapy. However, 16 patients received allopurinol besides potassium citrate.

Another issue that must be considered is the dietary and the fluid intake of the patients during the therapy. Did the patients modify their dietary and lifestyle?

A well-designed prospective study with larger patient number is required to validate these results.

Sincerely yours.

\section{References}

1. Gridley CM, Sourial MW, Lehman A, Knudsen BE (2019) Medical dissolution therapy for the treatment of uric acid nephrolithiasis. World J Urol 37(11):2509-2515. https://doi.org/10.1007/ s00345-019-02688-9

2. Ganesan V, De S, Greene D, Torricelli FC, Monga M (2017) Accuracy of ultrasonography for renal stone detection and size determination: is it good enough for management decisions? BJU Int 119(3):464-469. https://doi.org/10.1111/bju.13605

3. Brahee DD, Ogedegbe C, Hassler C, Nyirenda T, Hazelwood V, Morchel H, Patel RS, Feldman J (2013) Body mass index and abdominal ultrasound image quality. J Diagn Med Sonogr 29(2):66-72. https://doi.org/10.1177/8756479313476919

4. Wiederkehr MR, Moe OW (2011) Uric acid nephrolithiasis: a systemic metabolic disorder. Clin Rev Bone Miner Metab 9(34):207-217. https://doi.org/10.1007/s12018-011-9106-6

Publisher's Note Springer Nature remains neutral with regard to jurisdictional claims in published maps and institutional affiliations.

This comment refers to the article available at https://doi. org/10.1007/s00345-019-02688-9.

Senol Tonyali

senoltonyali@hotmail.com

1 Istanbul Universitesi Istanbul Tip Fakultesi, Uroloji

Anabilim Dali, Cerrahi Monoblok Kat:1 Capa-Fatih,

Istanbul, Turkey 